\title{
A simple strategy for improving the energy conversion of multilayered CdTe quantum dot-sensitized solar cells $\dagger$
}

\author{
Guo-Yu Lan, Zusing Yang, Yang-Wei Lin, Zong-Hong Lin, Hao-Ying Liao and Huan-Tsung Chang*
}

Received 29th September 2008, Accepted 16th January 2009

First published as an Advance Article on the web 23rd February 2009

DOI: $10.1039 / \mathrm{b817000b}$

In this paper we describe the preparation of CdTe quantum dot-sensitized solar cells (QDSSCs). We coated FTO substrates with $21 \mathrm{~nm}$-diameter $\mathrm{TiO}_{2}$ nanoparticles (NPs) and then immersed the system in poly(dimethyldiallylammonium chloride) (PDDA) solution under ambient conditions. The treated substrates were then subjected to $3 \mathrm{~nm}$-diameter CdTe NP solution at $100{ }^{\circ} \mathrm{C}$ for various periods of times. To increase the degree of deposition and to obtain CdTe QDs of various sizes, we performed the coating of the CdTe QDs through three heating cycles for 24, 12, or $6 \mathrm{~h}$. The as-prepared $\left(\mathrm{TiO}_{2}\right)_{3^{-}}$ PDDA- $\left(\mathrm{QD}_{\mathrm{CdTe}}\right)_{3}$-FTO electrodes were then used to fabricate $\left(\mathrm{TiO}_{2}\right)_{3}-\mathrm{PDDA}-\left(\mathrm{QD}_{\mathrm{CdTe}}\right)_{3}-\mathrm{FTO}$ QDSSCs employing 1-ethyl-3-methylimidazolium thiocyanate incorporating 1.0 M LiI and $0.1 \mathrm{M} \mathrm{I}_{2}$ as electrolytes. The heating treatment allows the QDSSCs to harvest energy at a higher efficiency in the visible region of solar light. As a result, the as-prepared QDSSCs feature a high energy conversion efficiency $(\eta=2.02 \%)$ and a high open-circuit photovoltage $\left(V_{\mathrm{oc}}=850 \mathrm{mV}\right)$ at $100 \%$ sunlight $(\mathrm{AM} 1.5$, $\left.100 \mathrm{~mW} / \mathrm{cm}^{2}\right)$.

\section{Introduction}

Because of the recent trends in global warming and the significant increase in the price of oil, ${ }^{1}$ the development of environmentally clean energy resources has become a critical issue. ${ }^{1}$ Single-crystalline $\mathrm{SiO}_{2}$-based chips are at present the most commonly used materials for the fabrication of solar cells, mainly because of their high energy conversion efficiency $(\eta>$ $22.6 \%)^{2}$ Nevertheless, their high cost limits their practical applicability. Dye-sensitized solar cells (DSSCs), on the other hand, offer the advantages of low cost, moderate values of $\eta$ (e.g., 10\%), and flexibility (e.g., they can be used on plastic substrates); as a result, they have become more popular materials for fabrication of solar cells. ${ }^{3-5}$ Ruthenium complex-based photosensitizers (e.g., $\mathrm{N}_{3}$ dye) and nanocrystalline $\mathrm{TiO}_{2}$ films can be used to prepare DSSCs that provide a value of $\eta$ of $c a .10 \%$ at $100 \%$ sunlight $\left(\mathrm{AM} 1.5,100 \mathrm{~mW} / \mathrm{cm}^{2}\right){ }^{3-5}$ The use of these DSSCs can be problematic, however, because of their high cost and short lifetime.

Quantum dots (QDs), which are easy to prepare on a large scale and absorb strongly in the visible region, have become interesting and possibly cost-effective sensitizers for the fabrication of solar cells. QDs have unique size-dependent optical properties, tunable visible responses and variable band offsets that allow modulation of the vectorial charge transfer, and generate multiple charge carriers from a single photon. ${ }^{6-9}$ The semiconductors used most commonly in QD-sensitized solar cells (QDSSCs) are InP $,{ }^{10} \mathrm{PbS},{ }^{11} \mathrm{CdSe},{ }^{12}$ and InAs, ${ }^{13}$ which have smaller band gaps to those of semiconductors such as $\mathrm{TiO}_{2}$ and

Department of Chemistry, National Taiwan University, 1, Section 4, Roosevelt Road, Taipei 106, Taiwan. E-mail: changht@ntu.edu.tw; Fax: +886-2-33661171; Tel: +886-2-33661171

$\uparrow$ Electronic supplementary information (ESI) available: Supplementary Fig. S1-S3. See DOI: 10.1039/b817000b
$\mathrm{SnO}_{2}$. Unfortunately, QDSSCs provide lower $\eta$ values relative to most DSSCs, which possess high photoelectrical efficiency over a large span of the visible light spectrum under direct irradiation with sunlight. ${ }^{14}$ Another reason for the low efficiencies of QDSSCs is that the QDs are generally not bound effectively to the $\mathrm{TiO}_{2}$ nanoparticles (NPs), leading to low deposition of QDs on the $\mathrm{TiO}_{2}$ surface. ${ }^{12}$ It has been noted previously that the formation of stable complexes between the sensitizers and the $\mathrm{TiO}_{2}$ NPs is essential to achieve high degrees of deposition of the sensitizers. ${ }^{15}$ Indeed, QD surfaces have been modified with bifunctional molecules, such as mercaptopropionic acid (MPA), to improve the binding and the efficiency of the photoinduced charge transfer between CdSe QDs and either $\mathrm{TiO}_{2} \mathrm{NPs}$ or $\mathrm{TiO}_{2}$ nanotubes. ${ }^{12,16}$ InAs QDs capped with trioctylphosphine oxide (TOPO) and trioctylphosphine (TOP) as sensitizers have been used to prepare QDSSCs on $\mathrm{TiO}_{2}$ films, resulting in values of $\eta$ of up to 1.7 and $0.3 \%$, respectively, under illumination at 5 and 100 $\mathrm{mW} / \mathrm{cm}^{2}$, respectively. ${ }^{13}$ In these cases, the increased binding between the InAs QDs and the $\mathrm{TiO}_{2}$ NPs was due to the strong interactions between phosphate residues and $\mathrm{Ti}^{13,17}$

Volatile and toxic organic solvents, such as acetonitrile, methoxyacetonitrile, and 3-methoxypropionitrile, are commonly used for the preparation of QDSSCs.,18,19 These organic solvents are environmentally unfriendly and vaporize readily, leading to QDSSCs exhibiting short lifetimes. To overcome these problems, highly ionically conductive, nonvolatile, and thermally stable room temperature ionic liquids (RTILs) are more suitable for use in the preparation of DSSCs. ${ }^{20-22}$ In addition, the charge transport rate of the $\mathrm{I}^{-} / \mathrm{I}_{3}{ }^{-}$redox couple can be promoted effectively within RTILs at a high concentration. For instance, the short circuit photocurrent density $\left(I_{\mathrm{sc}}\right)$ of DSSCs is enhanced when using RTILs containing a high concentration of the $\mathrm{I}^{-} / \mathrm{I}_{3}{ }^{-}$ redox couple. ${ }^{20-22}$ RTILs such as 1-dodecyl-3-methylimidazolium iodide, 1-propyl-3-methylimidazolium iodide, and 
1-ethyl-3-methylimidazolium thiocyanate have been used to increase the ionic conductivity and, thus, provide DSSCs exhibiting high current densities and photoelectric conversions. ${ }^{23,24}$

In this study, we used poly(dimethyldiallylammonium chloride) (PDDA) to link CdTe QDs to $\mathrm{TiO}_{2}$ NPs through electrostatic attraction. We expected that CdTe QDs having a high extinction coefficient $\left(4.4 \times 10^{4} \mathrm{M}^{-1} \mathrm{~cm}^{-1}\right)$ at $370 \mathrm{~nm}$ and valence band, conduction band, and band gap energies of $-3.9,-5.5$, and $+1.6 \mathrm{eV}$, respectively, would behave as sensitizers capable of effectively injecting electrons into $\mathrm{TiO}_{2} \mathrm{NPs}$ (band gap: $3.4 \mathrm{eV}){ }^{25,26}$ Through thermal processing, we prepared $\left(\mathrm{TiO}_{2}\right)_{m^{-}}$ PDDA-(QD $\left(\mathrm{CdTe}_{n}\right)_{n}$-FTO electrodes that we used in the fabrication of QDSSCs. ${ }^{27}$ In the QDSSCs, we used 1-ethyl-3methylimidazolium thiocyanate (EMImSCN) as the solvent to prepare $\mathrm{I}^{-} / \mathrm{I}_{3}{ }^{-}$electrolytes because of its high conductivity $(2.1 \mathrm{~S} /$ $\mathrm{m})$ and low viscosity ( $21 \mathrm{mPas})$ at room temperature, relative to those of other RTILs. ${ }^{28}$ We investigated the impact that the heating process of coating CdTe QDs on $\left(\mathrm{TiO}_{2}\right)_{3}$-PDDA-FTO substrates at $100{ }^{\circ} \mathrm{C}$ had in determining the optical properties and $\eta$ values of the QDSSCs.

\section{Experimental}

\section{Chemicals and instruments}

$\mathrm{TiO}_{2}$ NPs having diameters of $21 \pm 4.5 \mathrm{~nm}$ (P25, Degussa), cadmium perchlorate $\left[\mathrm{Cd}\left(\mathrm{ClO}_{4}\right)_{2}, 99 \%\right]$, tellurium powder (200 mesh, 99.8\%), ethylene glycol $(99 \%)$, hydrogen hexachloroplatinate(IV) hexahydrate $\left(\mathrm{H}_{2} \mathrm{PtCl}_{6} \cdot 6 \mathrm{H}_{2} \mathrm{O}, 99 \%\right)$, PDDA ( $M_{\mathrm{w}} 400000-500000,20 \mathrm{wt} \%$ aqueous solution), MPA (99+\%), sodium hydroxide, poly(vinylpyrrolidone) (PVP, $M_{\mathrm{w}} 55000$ ), methyl cellulose (2.0 $\mathrm{wt} \%$ aqueous solution), polyethylene glycol (PEG, $M_{\mathrm{w}} 5000$ ), and EMImSCN were purchased from SigmaAldrich (Milwaukee, WI, USA).

High-resolution transmission electron microscopy (HR-TEM) images were recorded using an H-7100 TEM system (Hitachi, Tokyo, Japan). Energy-dispersive X-ray (EDX) spectra were obtained using the HR-TEM system. Scanning electron microscopy (SEM) images were obtained using an ERA-8800 SEM system (Elionix, Tokyo, Japan). Nitrogen $\left(\mathrm{N}_{2}\right)$ adsorption/ desorption isotherms of $\mathrm{TiO}_{2}$ NP films were measured using a Micromeritics Tristar 3000 apparatus (Particle \& Surface Science, Pty. Ltd., NSW, Australia) at liquid nitrogen temperature. Before the measurements, the samples were degassed at 100 ${ }^{\circ} \mathrm{C}$ for $12 \mathrm{~h}$. The specific surface areas were evaluated using the Brunauer-Emmett-Teller (BET) method.

A double-beam UV-Vis spectrophotometer (Cintra 10e, GBC, VIC, Australia) was used to measure the absorption of CdTe QDs. The photocurrent-voltage $(I-V)$ curves were measured under the illumination provided by a solar simulator (Oriel 6691 450-W xenon arc lamp, CT, USA) at 100\% sunlight (AM1.5, 100 $\mathrm{mW} / \mathrm{cm}^{2}$ ). A Si photodetector (Photonic Solutions, Edinburgh, UK) was used as a reference. An Autolab potentiostat/galvanostat (Eco Chemie B.V., Kanaalweg, Netherlands) was used to record the $I-V$ characteristic of the as-prepared QDSSCs. Photocurrent and open-circuit photovoltages $\left(V_{\text {oc }}\right)$ were measured using a Keithley 2400 programmable electrometer (Test Equipment Connection Corporation, Lake Mary, FL,
USA). The incident photon-to-current conversion efficiency (IPCE) was measured using a high-intensity grating monochromator (Spectra-Physics, Oriel Cornerstone 130); the light intensity was measured using an OPHIR 2A-SH thermopile detector (Oriel, CT, USA).

\section{Preparation of CdTe QDs}

Water-soluble CdTe QDs were prepared using a method described previously. ${ }^{29}$ Briefly, $\mathrm{NaBH}_{4}(0.08 \mathrm{~g})$ was reacted with Te powder $(0.127 \mathrm{~g})$ in water $(1.0 \mathrm{~mL})$ to produce sodium hydrogen telluride (NaHTe, $0.99 \mathrm{M})$. The NaHTe solution $(0.5$ $\mathrm{mL}$ ) was then added to a $\mathrm{N}_{2}$-saturated mixture $(74.8 \mathrm{~mL} ; \mathrm{pH}$ 11.2) of MPA $(38 \mathrm{mM})$ and $\mathrm{Cd}\left(\mathrm{ClO}_{4}\right)_{2}(16 \mathrm{mM})$ to give a final $\mathrm{Cd}^{2+} / \mathrm{MPA} / \mathrm{HTe}^{-}$molar ratio of $1: 2.4: 0.5$. This mixture was then heated under reflux at $80{ }^{\circ} \mathrm{C}$ for $20 \mathrm{~min}$. The color of the solution changed from dark red to orange-yellow, indicating the formation of CdTe QDs that fluoresced at $505 \mathrm{~nm}$ when excited at $350 \mathrm{~nm}$. The CdTe QDs were purified by using 10k membranes (Millipore, Carrigtwohill, Co Cork, Ireland), which allowed removal of free ligands such as MPA and unreacted precursor ions from the CdTe QDs. The as-prepared CdTe QDs ( $c a .3 \mathrm{~nm})$ were characterized using HR-TEM and EDX spectroscopy (Fig. S1 $\dagger$ ). UV-Vis absorption measurements ${ }^{30}$ revealed that the concentration of CdTe QDs was $c a .50 \mu \mathrm{M}$.

\section{Synthesis of Pt NPs}

Pt NPs were synthesized using the polyol method. ${ }^{31}$ In a typical synthesis, PVP $(0.14 \mathrm{~g})$ was added to a solution of $0.01 \mathrm{M}$ $\mathrm{H}_{2} \mathrm{PtCl}_{6} \cdot 6 \mathrm{H}_{2} \mathrm{O}$ in ethylene glycol $(50 \mathrm{~mL})$ and then the mixture was heated at $160{ }^{\circ} \mathrm{C}$ for at least $2 \mathrm{~h}$. The color of the solution turned black, indicating the formation of Pt NPs. The as-prepared Pt NPs were subjected to three centrifugation/wash cycles (15000 rpm for $10 \mathrm{~min}$ ) and then they were stored in ethanol prior to use. A HR-TEM image (not shown) revealed that the diameters of the as-prepared Pt NPs were $4.9 \pm 1.1 \mathrm{~nm}$.

\section{Preparation of $\left(\mathrm{TiO}_{2}\right)_{m}$-PDDA-FTO substrates}

$\mathrm{TiO}_{2}$ powder $(6.0 \mathrm{~g})$ was stirred in diluted aqueous $\mathrm{HNO}_{3}$ solution $\left(1: 120, v / v^{0} \%\right)$ under heating at $80{ }^{\circ} \mathrm{C}$. After $8 \mathrm{~h}$, the dispersion was dried in a rotary evaporator to provide a $\mathrm{TiO}_{2} /$ $\mathrm{NO}_{3}{ }^{-}$powder (i.e., $\mathrm{HNO}_{3}$ adsorbed on the $\mathrm{TiO}_{2}$ surface). Coating pastes were prepared by mixing $\mathrm{TiO}_{2} / \mathrm{NO}_{3}{ }^{-}(0.8 \mathrm{~g}), \mathrm{H}_{2} \mathrm{O}$ (4 mL), methyl cellulose ( $0.08 \mathrm{~g})$, and PEG (0.24 g); methyl cellulose and PEG were used as thickening and porosityincreasing materials, respectively. ${ }^{32}$ The modified $\mathrm{TiO}_{2}$ paste was degassed and then coated on F-doped tin oxide (FTO) substrates (electrodes) using the doctor-blade technique. ${ }^{33,34}$ The area of each of the conducting FTO substrates was $1.5 \times 2.0 \mathrm{~cm}^{2}$ (transmission: $>90 \%$; sheet resistance: $9 \Omega \mathrm{sq}^{-1}$ ). The two edges of each FTO substrate were sealed using adhesive tape. The FTO substrates, each covered with a $\mathrm{TiO}_{2}$ film, were then dried at $50{ }^{\circ} \mathrm{C}$. One to three coating/heating cycles were used to fabricate the $\left(\mathrm{TiO}_{2}\right)_{m}$-FTO substrates $(m=1-3)$. The $\left(\mathrm{TiO}_{2}\right)_{m}$-FTO substrates $(m=1-3)$ were then sintered at $450{ }^{\circ} \mathrm{C}$ for $30 \mathrm{~min}$ in dry air. After thermal annealing, the $\left(\mathrm{TiO}_{2}\right)_{m}$-FTO substrates were immersed overnight in a solution of $4 \%$ PDDA containing $0.5 \mathrm{M} \mathrm{NaCl}$ to prepare the $\left(\mathrm{TiO}_{2}\right)_{m}$-PDDA-FTO substrates 
(A)

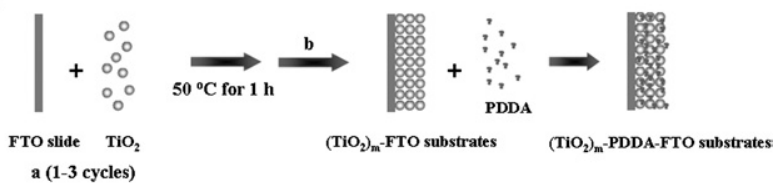

(B)

$\left(\mathrm{TiO}_{2}\right)_{3}-\mathrm{PDDA}-\left(\mathrm{QD}_{\mathrm{CdTe}}\right)_{\mathrm{n}}$-FTO electrodes

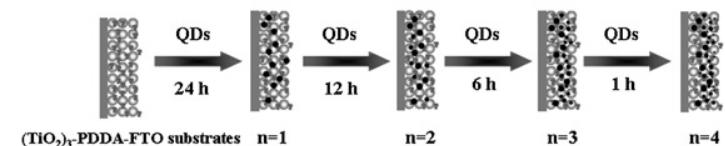

Scheme 1 (A) Fabrication processes employed to prepare the $\left(\mathrm{TiO}_{2}\right)_{m}$-PDDA-FTO substrates $(m=1-3)$. (a) $\mathrm{TiO}_{2}$-FTO substrate prepared using a doctor-blade technique and then dried at $50^{\circ} \mathrm{C}$ for $1 \mathrm{~h}$ in each preparation cycle. (b) Sintering at $450{ }^{\circ} \mathrm{C}$ for $30 \mathrm{~min}$. The dry $\left(\mathrm{TiO}_{2}\right)_{m}$-FTO substrates were then immersed separately in PDDA solutions for $12 \mathrm{~h}$. (B) Fabrication processes employed for the preparation of the $\left(\mathrm{TiO}_{2}\right)_{3}$-PDDA- $\left(\mathrm{QD}_{\mathrm{CdTe}}\right)_{n}$-FTO $(n=1-4)$ electrodes at $100{ }^{\circ} \mathrm{C}$, with heating times of $24,12,6$, and $1 \mathrm{~h}$ for the first to fourth cycles, respectively. Solid circles represent CdTe QDs.

(Scheme 1A), which each had an effective area of $0.16 \mathrm{~cm}^{2} .{ }^{27}$ The substrates were subjected to air drying and then rinsing with DI water and ethanol to remove any unbound PDDA.

\section{Fabrication of $\left(\mathrm{TiO}_{2}\right)_{3}-\mathrm{PDDA}-\left(\mathrm{QD}_{\mathrm{CdTe}}\right)_{n}$-FTO electrodes}

The $\left(\mathrm{TiO}_{2}\right)_{3}$-PDDA- $\left(\mathrm{QD}_{\mathrm{CdTe}}\right)_{n}$-FTO electrodes $(n=1-4)$ were obtained by immersing the $\left(\mathrm{TiO}_{2}\right)_{3}$-PDDA-FTO substrates into CdTe QD solution $\left(\lambda_{\mathrm{em}}=505 \mathrm{~nm} ; 50 \mu \mathrm{M}, 5 \mathrm{~mL}\right)$ and then heating at $100{ }^{\circ} \mathrm{C}$ in an oven (Scheme 1B). This temperature was chosen to increase the coverage area of the CdTe QDs on the $\mathrm{TiO}_{2}$-PDDA-FTO substrates; it also allowed the band edge of the CdTe QDs on the $\left(\mathrm{TiO}_{2}\right)_{3}$-PDDA- $\left(\mathrm{QD}_{\mathrm{CdTe}}\right)_{n}$-FTO electrodes to be tuned by controlling the reaction time in each step. The $\left(\mathrm{TiO}_{2}\right)_{3}$-PDDA-FTO substrates prepared after conducting the first step for $24 \mathrm{~h}$ are denoted herein as the $\left(\mathrm{TiO}_{2}\right)_{3}$-PDDA$\left(\mathrm{QD}_{\mathrm{CdTe}}\right)_{1}$-FTO electrodes. The $\left(\mathrm{TiO}_{2}\right)_{3}$-PDDA- $\left(\mathrm{QD}_{\mathrm{CdTe}}\right)_{1}$-FTO electrodes were then placed in a freshly prepared CdTe QDs solution $\left(\lambda_{\mathrm{em}}=505 \mathrm{~nm} ; 50 \mu \mathrm{M}\right)$ for $12 \mathrm{~h}$ to perform the second coating step, providing the $\left(\mathrm{TiO}_{2}\right)_{3}$-PDDA- $\left(\mathrm{QD}_{\mathrm{CdTe}}\right)_{2}-\mathrm{FTO}$ electrodes. Similarly, the $\left(\mathrm{TiO}_{2}\right)_{3}-\mathrm{PDDA}-\left(\mathrm{QD}_{\mathrm{CdTe}}\right)_{2}-\mathrm{FTO}$ electrodes were used to prepare the $\left(\mathrm{TiO}_{2}\right)_{3}-\mathrm{PDDA}-\left(\mathrm{QD}_{\mathrm{CdTe}}\right)_{3}-\mathrm{FTO}$ electrodes, which were then used to prepare the $\left(\mathrm{TiO}_{2}\right)_{3}$-PDDA$\left(\mathrm{QD}_{\mathrm{CdTe}}\right)_{4}$-FTO electrodes, at the third and fourth coating times of 6 and $1 \mathrm{~h}$, respectively. All of these as-prepared $\left(\mathrm{TiO}_{2}\right)_{3}$-PDDA-(QD $\left.\mathrm{CdTe}_{n}\right)_{n}$-FTO electrodes $(n=1-4)$ were cleaned sequentially with doubly distilled $\mathrm{H}_{2} \mathrm{O}$ and ethanol and then dried at $100{ }^{\circ} \mathrm{C}$.

\section{Fabrication of $\left(\mathrm{TiO}_{2}\right)_{3}-\mathrm{PDDA}-\left(\mathrm{QD}_{\mathrm{CdTe}}\right)_{n}$-FTO QDSSCs}

The as-prepared $\left(\mathrm{TiO}_{2}\right)_{3}$-PDDA- $\left(\mathrm{QD}_{\mathrm{CdTe}}\right)_{n}$-FTO electrodes $(n=$ 1-4) were dried in an oven at $100{ }^{\circ} \mathrm{C}$ for at least $1 \mathrm{~h}$. Counter electrodes were prepared by placing a drop of the Pt NPs onto the FTO glass substrates and drying at $100{ }^{\circ} \mathrm{C}$ for $30 \mathrm{~min}$. The Ptcoated counter electrodes were then sintered at $450{ }^{\circ} \mathrm{C}$ for 30 min. The $\left(\mathrm{TiO}_{2}\right)_{3}$-PDDA- $\left(\mathrm{QD}_{\mathrm{CdTe}}\right)_{n}$-FTO electrodes $(n=1-4)$ and Pt-coated counter electrodes were assembled in a sandwich configuration and sealed with a spacer, after annealing at $100{ }^{\circ} \mathrm{C}$ for $1 \mathrm{~h}$. The as-prepared $\left(\mathrm{TiO}_{2}\right)_{3}-\mathrm{PDDA}-\left(\mathrm{QD}_{\mathrm{CdTe}}\right)_{n}$-FTO QDSSCs $(n=1-4)$ were placed in an oven at $100{ }^{\circ} \mathrm{C}$ for $1 \mathrm{~h}$ to avoid the absorption of water prior to use in the experiment. An EMImSCN solution containing $1.0 \mathrm{M} \mathrm{LiI}$ and $0.1 \mathrm{M} \mathrm{I}_{2}$ as electrolytes was injected into each of the $\left(\mathrm{TiO}_{2}\right)_{3}$-PDDA$\left(\mathrm{QD}_{\mathrm{CdTe}}\right)_{n}$-FTO QDSSCs $(n=1-4) .{ }^{35}$ To enhance the conductivity of electrodes, $\mathrm{Cu}$ tapes were pasted on the $\left(\mathrm{TiO}_{2}\right)_{3}$-PDDA$\left(\mathrm{QD}_{\mathrm{CdTe}}\right)_{n}$-FTO QDSSCs $(n=1-4)$.

\section{Results and discussion}

\section{Preparation of $\left(\mathrm{TiO}_{2}\right)_{m}$-PDDA-FTO sfubstrates and $\left(\mathrm{TiO}_{2}\right)_{3^{-}}$ PDDA-(QD $\left.{ }_{\mathrm{CdTe}}\right)_{n}$-FTO electrodes}

Scheme 1A displays the doctor-blade method we used to fabricate the $\left(\mathrm{TiO}_{2}\right)_{m}$-FTO substrates $(m=1-3) .{ }^{27}$ The $\left(\mathrm{TiO}_{2}\right)_{m}$-FTO substrates were then modified with PDDA to prepare the $\left(\mathrm{TiO}_{2}\right)_{m}$-PDDA-FTO substrates $(m=1-3)$. At pH $10.5, \mathrm{TiO}_{2}$ NPs $(\mathrm{pI}=4.5)$ possess negatively charged surfaces, whereas PDDA is positively charged; therefore, they interact through electrostatic attraction. Fig. 1 displays SEM images of the surface morphologies of the $\left(\mathrm{TiO}_{2}\right)_{m}$-PDDA-FTO substrates $(m$ $=1-3$ ). The surface of each of the coating films was smooth, with no cracks appearing on the surface of the $\mathrm{TiO}_{2}$ film. From the SEM and BET analyses, we estimated the $\left(\mathrm{TiO}_{2}\right)_{m}$-PDDA-FTO ( $m=1-3$ ) substrates to have thicknesses of 26.6, 46.6, and $61.3 \mu \mathrm{m}$, respectively, and specific surface areas of 48.1, 52.1, and $54.3 \mathrm{~m}^{2} \mathrm{~g}^{-1}$, respectively. Thus, the amount of $\mathrm{TiO}_{2} \mathrm{NPs}$ on (a)

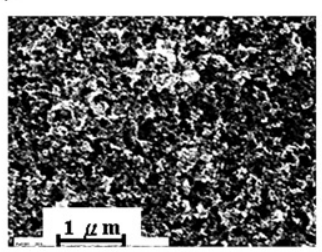

(b)

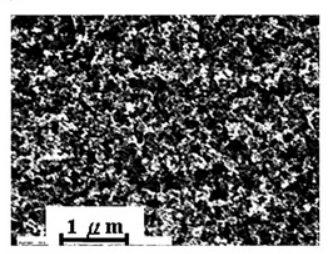

(c)

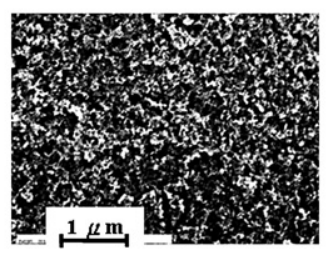

(d)

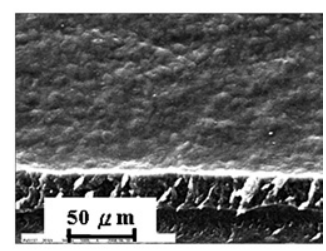

(e)

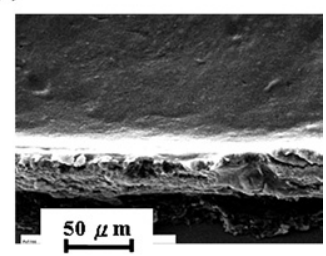

(f)

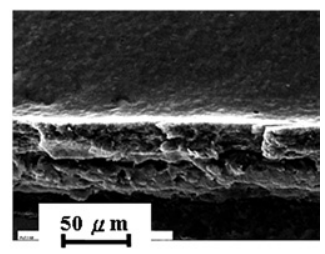

Fig. 1 (a-c) Top-view SEM images of the (a) $\left(\mathrm{TiO}_{2}\right)_{1}$-PDDA-FTO, (b) $\left(\mathrm{TiO}_{2}\right)_{2}$-PDDA-FTO, and (c) $\left(\mathrm{TiO}_{2}\right)_{3}$-PDDA-FTO substrates and (d-e) cross-sectional SEM images of the (d) $\left(\mathrm{TiO}_{2}\right)_{1}$-PDDA-FTO, (e) $\left(\mathrm{TiO}_{2}\right)_{2}$-PDDA-FTO, and (f) $\left(\mathrm{TiO}_{2}\right)_{3}$-PDDA-FTO substrates. 
the $\left(\mathrm{TiO}_{2}\right)_{m}$-PDDA-FTO substrates increased upon increasing the value of $m$ (i.e., the number of heating cycles). We expected that a greater amount and larger surface area of $\mathrm{TiO}_{2} \mathrm{NPs}$ on the substrates would increase the electron transfer efficiency of the substrates. In addition, we expected that more PDDA molecules would be present on the films, leading to an increased loading of CdTe QDs. The $\mathrm{TiO}_{2}$ film of the $\left(\mathrm{TiO}_{2}\right)_{4}$-PDDA-FTO substrate became too fragile for use in the fabrication of the $\left(\mathrm{TiO}_{2}\right)_{4}$-PDDA-(QD $\left.\mathrm{CdTe}\right)_{n}$-FTO electrodes $(n=1-4)$. Thus, we used the $\left(\mathrm{TiO}_{2}\right)_{3}$-PDDA-FTO substrates to fabricate the $\left(\mathrm{TiO}_{2}\right)_{3}$-PDDA-(QD $\left.\mathrm{CdTe}_{n}\right)_{n}$-FTO electrodes.

Scheme 1B displays the processes that we used for the fabrication of the $\left(\mathrm{TiO}_{2}\right)_{3}$-PDDA- $\left(\mathrm{QD}_{\mathrm{CdTe}}\right)_{n}$-FTO electrodes $(n=1-4)$ at $100{ }^{\circ} \mathrm{C}$, prepared through one to four heating cycles, each for a different length of time. The CdTe QDs were bound to the $\mathrm{TiO}_{2}$ NPs through electrostatic interactions with surface-bound PDDA. We conducted multiple coating steps and used various heating times to increase the amounts of the differently sized CdTe QDs that adsorbed onto the $\left(\mathrm{TiO}_{2}\right)_{3}$-PDDA-FTO substrates. The SEM images of the surface morphologies of the $\left(\mathrm{TiO}_{2}\right)_{3}$-PDDA(QD) ${ }_{n}$-FTO electrodes $(n=1-4)$ are shown in Fig. S2. $\dagger$ While heating at $100{ }^{\circ} \mathrm{C}$, the sizes of the CdTe QDs increased as a result of Ostwald ripening. ${ }^{36}$ The sizes also increased upon increasing the reaction time (see the detailed discussion in the next section). As a result of inefficient binding of the larger-sized CdTe QDs to the $\mathrm{TiO}_{2}$ NPs, some spaces in the $\mathrm{TiO}_{2}$ films remained for the binding of more smaller-sized CdTe QDs. Thus, the reaction time decreased for each subsequent heating cycle: $24,12,6$, and $1 \mathrm{~h}$ for the first to fourth cycles, respectively.

\section{Optical properties of $\left(\mathrm{TiO}_{2}\right)_{3}-\mathrm{PDDA}-\left(\mathrm{QD}_{\mathrm{CdTe}}\right)_{n}$-FTO electrodes}

To test the suitability of using the $\left(\mathrm{TiO}_{2}\right)_{3}$-PDDA$\left(\mathrm{QD}_{\mathrm{CdTe}}\right)_{n}$-FTO electrodes $(n=1-4)$ for the fabrication of QDSSCs, we measured their absorption properties. Fig. 2A reveals that the absorbance at $c a$. $600 \mathrm{~nm}$ increased upon increasing the value of $n$ from 1 to 3 , but it decreased from 3 to 4 . We observed wider absorption peak profiles upon increasing $n$, mainly due to the coating of the different sizes of CdTe QDs; the increases in absorbance were due mainly to the greater amounts of the CdTe QDs adsorbed on the $\mathrm{TiO}_{2}$ film. The ICP-MS results shown in the inset of Fig. 2A also demonstrated that the contents of CdTe QDs in the $\left(\mathrm{TiO}_{2}\right)_{3}$-PDDA-(QD) ${ }_{n}$-FTO electrodes increased upon increasing the values of $n$ from 1 to 3 and then it decreased upon increasing $n$ from 3 to 4 . Our success in achieving relatively high coverages of CdTe QDs in these $\mathrm{TiO}_{2}$ films arose mainly because we filled small-sized CdTe QDs into the porous networks of the $\mathrm{TiO}_{2}$ films. Although the absorbance at $c a .500$ $\mathrm{nm}$ of the $\left(\mathrm{TiO}_{2}\right)_{3}-\mathrm{PDDA}-\left(\mathrm{QD}_{\mathrm{CdTe}}\right)_{n}$-FTO electrodes increased upon increasing the value of $n$ from 3 to 4 , the absorbance decreased at wavelengths greater than $550 \mathrm{~nm}$, mainly because of the instability of the CdTe QD coating. In other words, some of the larger-sized CdTe QDs were replaced by smaller-sized CdTe QDs. Fig. S3† shows that the size distributions of CdTe QDs in the $\left(\mathrm{TiO}_{2}\right)_{3}$-PDDA-(QD) ${ }_{n}$-FTO electrodes $(n=1-4)$, which were determined by HR-TEM. Upon increasing the deposition cycles from the values of $n$ from 1 to 4 , the size distributions of CdTe QDs of each electrodes became broader, which are correlated with the wider absorption of CdTe QDs in the visible region.
(A)

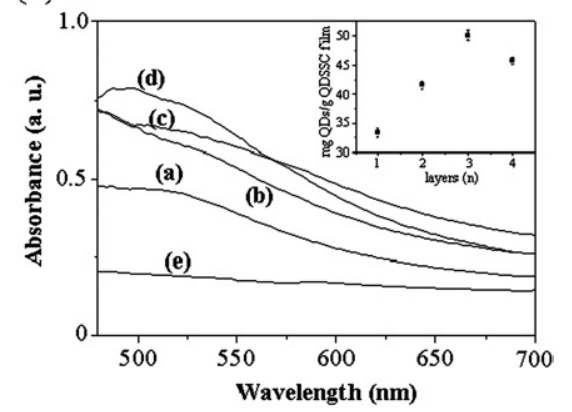

(B)

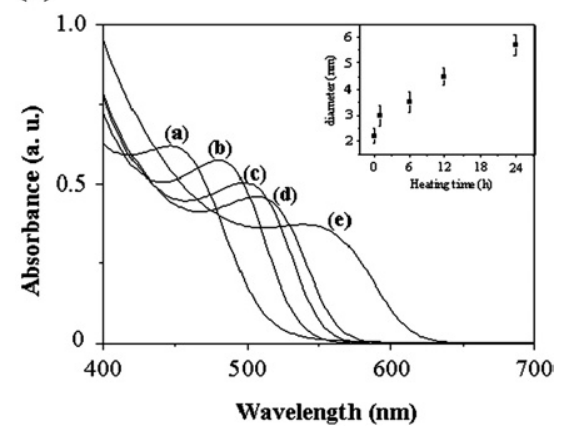

Fig. 2 (A) Absorption spectra of the (a) $\left(\mathrm{TiO}_{2}\right)_{3}-\mathrm{PDDA}-$ $\left(\mathrm{QD}_{\mathrm{CdTe}}\right)_{1}$-FTO, (b) $\left(\mathrm{TiO}_{2}\right)_{3}$-PDDA- $\left(\mathrm{QD}_{\mathrm{CdTe}}\right)_{2}-\mathrm{FTO}, \quad$ (c) $\left(\mathrm{TiO}_{2}\right)_{3}-$ PDDA- $\left(\mathrm{QD}_{\mathrm{CdTe}}\right)_{3}$-FTO, (d) $\left(\mathrm{TiO}_{2}\right)_{3}$-PDDA- $\left(\mathrm{QD}_{\mathrm{CdTe}}\right)_{4}$-FTO electrodes, and (e) $\left(\mathrm{TiO}_{2}\right)_{3}$-PDDA-FTO as control. Inset: contents of CdTe QDs in the $\left(\mathrm{TiO}_{2}\right)_{3}$-PDDA-(QD) $)_{n}$-FTO electrodes $(n=1-4)$. The concentrations of cadmium ions were determined by ICP-MS. (B) Absorption spectra of CdTe QD solutions heated at $100^{\circ} \mathrm{C}$ for (a) 0, (b) 1, (c) 6, (d) 12, and (e) 24 h. Inset: sizes of the CdTe QDs plotted with respect to the heating time.

The absorption spectrum of a sensitizer plays an important role in determining the energy conversion efficiency of DSSCs. ${ }^{12,16,37,38}$ We were encouraged that the relatively high absorption in the visible spectrum by our $\left(\mathrm{TiO}_{2}\right)_{3}$-PDDA- $\left(\mathrm{QD}_{\mathrm{CdTe}}\right)_{3}$-FTO electrode would ensure a greater absorption $(>80 \%)$ of the incident visible light. Our multilayer coverage of CdTe QDs on the $\mathrm{TiO}_{2}$ films is analogous to the modification of mesoscopic $\mathrm{TiO}_{2}$ films with sensitizing dyes. ${ }^{3-5}$ Our optical analysis suggested that the $\left(\mathrm{TiO}_{2}\right)_{3}$-PDDA-(QD $\left.\mathrm{CdTe}\right)_{3}-\mathrm{FTO}$ electrode would be the optimal structure for the fabrication of the QDSSCs.

To further understand the changes in the absorption spectra that occurred during the various heating processes, we conducted similar experiments using aqueous CdTe solutions. Fig. 2B reveals that red shifts in the absorption of the CdTe solutions occurred upon increasing the heating time from 1 to $24 \mathrm{~h}$. This situation arose mainly because Ostwald ripening (i.e., the atoms that dissolved from the smaller-sized CdTe QDs grew onto other CdTe QDs to form larger-sized CdTe QDs) occurred while heating at $100{ }^{\circ} \mathrm{C}$, leading to increases in the sizes of the CdTe QDs (see the inset to Fig. 2B), as evidenced from HR-TEM images. ${ }^{29}$ Heating for 24, 12, 6, and $1 \mathrm{~h}$ resulted in CdTe QDs having sizes of $5.7,4.5,3.5$, and $3.0 \mathrm{~nm}$, respectively. We noted that the absorption wavelengths underwent a red shift upon an increase in the size of the QDs. 


\section{Photocurrent-voltage characteristics of QDSSCs}

The energy diagram showing the operating principle of the QDSSC is depicted in Scheme 2A. At the heart of the system is a mesoscopic $\mathrm{TiO}_{2}$ film, which is placed in contact with a redox electrolyte. Photoexcitation of the CdTe QDs results in the injection of an electron into the conduction band of the $\mathrm{TiO}_{2}$ film. The electronic state of the CdTe QDs is regenerated by electron donation from the electrolyte such as the iodide/triiodide couple. The movement of holes on the QDs surface must be accompanied by the diffusion of charge-compensating anions in the electrolyte layer close to the CdTe QDs surface. The photogenerated holes in CdTe QDs could be scavenged by iodide ions as shown in Scheme 2B. ${ }^{39}$ Fig. 3 displays the $I-V$ curves, recorded at $100 \%$ sunlight (AM1.5, $100 \mathrm{~mW} / \mathrm{cm}^{2}$ ), for QDSSCs that we prepared from the $\left(\mathrm{TiO}_{2}\right)_{3}$-PDDA- $\left(\mathrm{QD}_{\mathrm{CdTe}}\right)_{n}$-FTO electrodes $(n$ $=1-4)$. Table 1 summarizes their values of $V_{\mathrm{oc}}, I_{\mathrm{sc}}$, fill factor (FF), and $\eta$. The magnitudes of the values of $I_{\mathrm{sc}}$ and $\eta$ of the QDSSCs correlate with the absorbances in Fig. 2A. This behavior is consistent with the knowledge that QDs having greater absorption coefficients usually provide greater values of $I_{\mathrm{sc}}$ and $\eta \cdot{ }^{39}$ The values of $I_{\mathrm{sc}}, \mathrm{FF}$, and $\eta$ of the $\left(\mathrm{TiO}_{2}\right)_{3}$-PDDA$\left(\mathrm{QD}_{\mathrm{CdTe}}\right)_{n}$-FTO QDSSCs increased upon increasing the value of $n$ from 1 to 3 , but then they decreased upon increasing $n$ from 3 to 4 . The values of $I_{\mathrm{sc}}, \mathrm{FF}$, and $\eta$ of the $\left(\mathrm{TiO}_{2}\right)_{3}$-PDDA$\left(\mathrm{QD}_{\mathrm{CdTe}}\right)_{3}$-FTO QDSSCs were $3.61 \mathrm{~mA} \mathrm{~cm}^{-2}, 65.8$, and $2.02 \%$, respectively. We note that the value of $\eta$ of our $\left(\mathrm{TiO}_{2}\right)_{3}-\mathrm{PDDA}-$ $\left(\mathrm{QD}_{\mathrm{CdTe}}\right)_{3}$-FTO QDSSC $(2.02 \%)$ is greater than those of QDSSCs fabricated from $\mathrm{CdS}, \mathrm{CdSe}, \mathrm{PbS}$, InAs, and InP, ${ }^{10-13,37,38}$ primarily because of the superior value of $V_{\mathrm{oc}}$ $(850 \mathrm{mV}) .{ }^{10-13,16,37,38}$ The values of $\eta$ of the $\left(\mathrm{TiO}_{2}\right)_{3}$-PDDA$\left(\mathrm{QD}_{\mathrm{CdTe}}\right)_{n}$-FTO QDSSC $(n=1-4)$ are greater than those of QDSSCs fabricated in the presence of PDDA at room

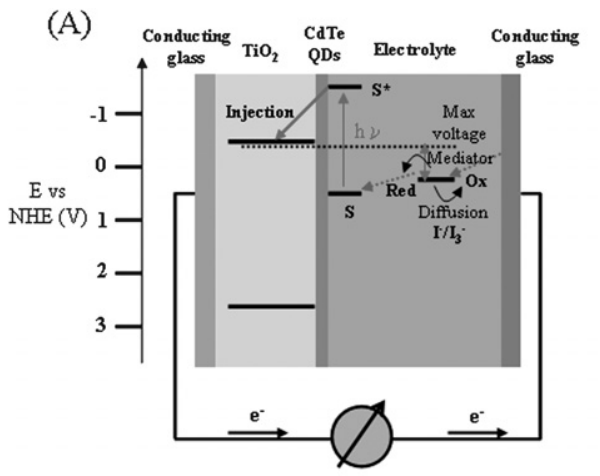

(B)

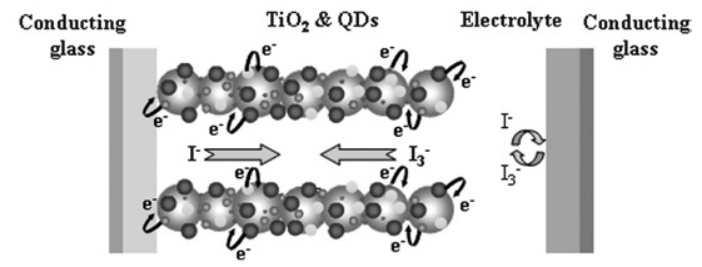

Scheme 2 (A) Principle of operation of the CdTe QDSSC. Potentials are referred to the normal hydrogen electrode (NHE). (B) Transmission line description of the electron motion through the conduction band of $\mathrm{TiO}_{2}$ particles. temperature and in the absence of PDDA at $100^{\circ} \mathrm{C}$, respectively. The amounts of CdTe QDs adsorbed on these substrates were less (about 5- and 3-fold lower) than the QDSSCs fabricated at $100{ }^{\circ} \mathrm{C}$ in the presence of PDDA, mainly because only fewer amounts of CdTe QDs were adsorbed, which were supported by

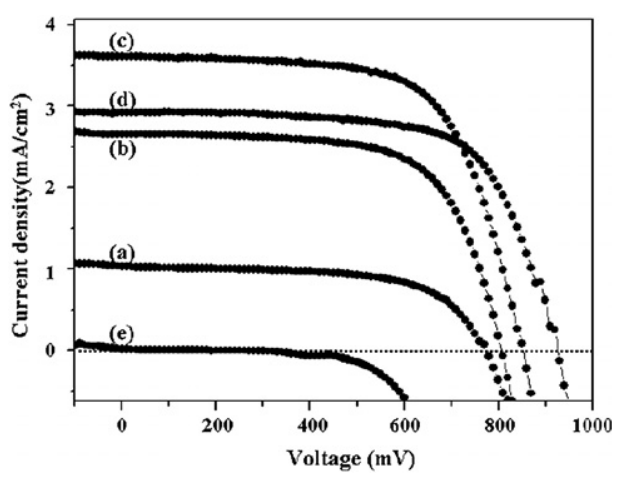

Fig. $3 I-V$ characteristics of the (a) $\left(\mathrm{TiO}_{2}\right)_{3}-\mathrm{PDDA}-\left(\mathrm{QD}_{\mathrm{CdTe}}\right)_{1}-\mathrm{FTO}$, (b) $\left(\mathrm{TiO}_{2}\right)_{3}-\mathrm{PDDA}-\left(\mathrm{QD}_{\mathrm{CdTe}}\right)_{2}-\mathrm{FTO}, \quad$ (c) $\left(\mathrm{TiO}_{2}\right)_{3}-\mathrm{PDDA}-\left(\mathrm{QD}_{\mathrm{CdTe}}\right)_{3}-\mathrm{FTO}$, (d) $\left(\mathrm{TiO}_{2}\right)_{3}$-PDDA-( $\left(\mathrm{QD}_{\mathrm{CdTe}}\right)_{4}$-FTO, and (e) $\left(\mathrm{TiO}_{2}\right)_{3}$-PDDA$\left(\mathrm{QD}_{\mathrm{CdTe}}\right)_{3}$-FTO QDSSCs. (a-d) Illumination with $100 \%$ sunlight (AM1.5, $100 \mathrm{~mW} / \mathrm{cm}^{2}$ ); (e) darkness.

Table 1 Performance characteristics of the CdTe QDSSCs

\begin{tabular}{|c|c|c|c|c|}
\hline QDSSCs & $I_{\mathrm{sc}}(\mathrm{mA} \mathrm{cm}-2)$ & $V_{\mathrm{oc}}(\mathrm{mV})$ & FF (\%) & $\eta(\%)$ \\
\hline $\begin{array}{l}\left(\mathrm{TiO}_{2}\right)_{3} \text {-PDDA- } \\
\left(\mathrm{QD}_{\mathrm{CdTe}}\right)_{1} \text {-FTO } \\
\text { electrode }\end{array}$ & 1.03 & 780 & 62 & 0.50 \\
\hline $\begin{array}{l}\left(\mathrm{TiO}_{2}\right)_{3} \text {-PDDA- } \\
\left(\mathrm{QD}_{\mathrm{CdTe}}\right)_{2} \text {-FTO } \\
\text { electrode }\end{array}$ & 2.65 & 800 & 67 & 1.42 \\
\hline $\begin{array}{l}\left(\mathrm{TiO}_{2}\right)_{3}-\mathrm{PDDA}- \\
\left(\mathrm{QD}_{\mathrm{CdTe}}\right)_{3}-\mathrm{FTO} \\
\text { electrode }\end{array}$ & 3.61 & 850 & 66 & 2.02 \\
\hline $\begin{array}{l}\left(\mathrm{TiO}_{2}\right)_{3} \text {-PDDA- } \\
\left(\mathrm{QD}_{\mathrm{CdTe}}\right)_{4} \text {-FTO } \\
\text { electrode }\end{array}$ & 2.92 & 920 & 65 & 1.83 \\
\hline $\begin{array}{l}{ }^{a}\left(\mathrm{TiO}_{2}\right)_{3}-\mathrm{PDDA}- \\
\left(\mathrm{QD}_{\mathrm{CdTe}}\right)_{1} \text {-FTO } \\
\text { electrode }\end{array}$ & 0.32 & 471 & 48 & 0.07 \\
\hline $\begin{array}{l}{ }^{a}\left(\mathrm{TiO}_{2}\right)_{3}-\mathrm{PDDA}- \\
\left(\mathrm{QD}_{\mathrm{CdTe}}\right)_{2}-\mathrm{FTO} \\
\text { electrode }\end{array}$ & 0.51 & 570 & 56 & 0.16 \\
\hline $\begin{array}{l}{ }^{a}\left(\mathrm{TiO}_{2}\right)_{3}-\mathrm{PDDA}- \\
\left(\mathrm{QD}_{\mathrm{CdTe}}\right)_{3} \text {-FTO } \\
\text { electrode }\end{array}$ & 0.72 & 569 & 57 & 0.34 \\
\hline $\begin{array}{l}{ }^{a}\left(\mathrm{TiO}_{2}\right)_{3}-\mathrm{PDDA}- \\
\left(\mathrm{QD}_{\mathrm{CdTe}}\right)_{4}-\mathrm{FTO} \\
\text { electrode }\end{array}$ & 0.77 & 510 & 58 & 0.20 \\
\hline $\begin{array}{c}{ }^{b}\left(\mathrm{TiO}_{2}\right)_{3}-\left(\mathrm{QD}_{\mathrm{CdTe}}\right)_{1}- \\
\text { FTO electrode }\end{array}$ & 0.78 & 641 & 43 & 0.21 \\
\hline $\begin{array}{c}{ }^{b}\left(\mathrm{TiO}_{2}\right)_{3}-\left(\mathrm{QD}_{\mathrm{CdTe}}\right)_{2^{-}} \\
\text {FTO electrode }\end{array}$ & 1.10 & 750 & 46 & 0.38 \\
\hline $\begin{array}{c}{ }^{b}\left(\mathrm{TiO}_{2}\right)_{3}-\left(\mathrm{QD}_{\mathrm{CdTe}}\right)_{3}{ }^{-} \\
\text {FTO electrode }\end{array}$ & 1.66 & 670 & 56 & 0.62 \\
\hline $\begin{array}{c}{ }^{b}\left(\mathrm{TiO}_{2}\right)_{3}-\left(\mathrm{QD}_{\mathrm{CdTe}}\right)_{4^{-}} \\
\text {FTO electrode }\end{array}$ & 1.35 & 679 & 60 & 0.55 \\
\hline
\end{tabular}

${ }^{a}$ Conducting the coating procedure at room temperature. Other conditions are the same as Scheme $1 \mathrm{~B} .{ }^{b}$ Conducting the coating procedure at $100{ }^{\circ} \mathrm{C}$ in the absence of PDDA. Other conditions are the same as Scheme 1B. 


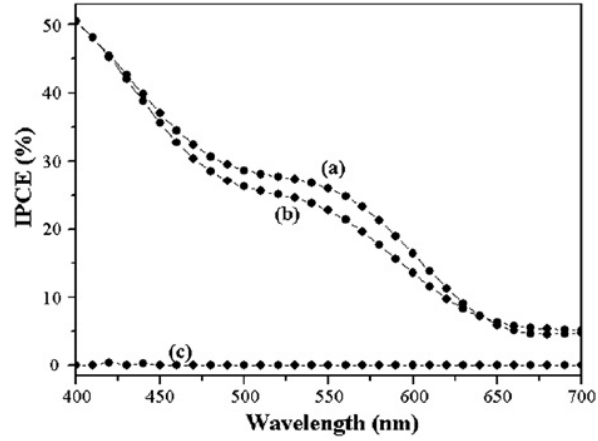

Fig. 4 IPCEs of the (a) $\left(\mathrm{TiO}_{2}\right)_{3}-\mathrm{PDDA}-\left(\mathrm{QD}_{\mathrm{CdTe}}\right)_{3}-\mathrm{FTO}$, (b) $\left(\mathrm{TiO}_{2}\right)_{3}$-PDDA-(QD $\left.\mathrm{CdTe}\right)_{4}$-FTO, and (c) $\left(\mathrm{TiO}_{2}\right)_{3}$-PDDA-FTO QDSSCs.

Table 2 Comparison of the CdTe QDSSC to other CdTe based QDSSCs

\begin{tabular}{|c|c|c|c|c|c|}
\hline Type & $I_{\mathrm{sc}}(\mathrm{mA} \mathrm{cm}-2)$ & $V_{\mathrm{oc}}(\mathrm{mV})$ & FF $(\%)$ & $\eta(\%)$ & Ref \\
\hline $\mathrm{CdSe} / \mathrm{CdTe} / \mathrm{TiO}_{2} \mathrm{NPs}$ & 0.0695 & 360 & 48 & 0.015 & 40 \\
\hline $\mathrm{CdTe} / \mathrm{TiO}_{2}$ nanotube & 0.44 & ${ }^{a}$ & 一 & - & 41 \\
\hline $\mathrm{CdTe} / \mathrm{TiO}_{2} \mathrm{NPs}$ & $5-9$ & 650 & 20 & - & 42 \\
\hline $\mathrm{CdTe} / \mathrm{TiO} 2 \mathrm{NPs}$ & 3.61 & 850 & 66 & 2.02 & This \\
\hline
\end{tabular}

${ }^{a}$ The value is not provided by the literature.

the ICP MS data. We suspect that the superior performance of our $\left(\mathrm{TiO}_{2}\right)_{3}$-PDDA-(QD $\left(\mathrm{CdTe}_{3}\right)_{3}$-FTO QDSSC arose because of the existence of CdTe QDs of various sizes, leading to more excited electrons being produced under illumination with visible light. The decreasing value of $\eta$ of the $\left(\mathrm{TiO}_{2}\right)_{3}$-PDDA$\left(\mathrm{QD}_{\mathrm{CdTe}}\right)_{n}$-FTO QDSSCs upon increasing the value of $n$ from 3 to 4 is strongly related to the reduction in the values of the FF and $I_{\mathrm{sc}}$, mainly because of decreases in the absorbance in the longer wavelength region and possibly because of blocking of the mesopores of the $\mathrm{TiO}_{2}$ NPs.

To further understand the role of the CdTe QDs in determining the value of $\eta$ of our QDSSCs, we conducted IPCE measurements of the $\left(\mathrm{TiO}_{2}\right)_{3}$-PDDA-FTO, $\left(\mathrm{TiO}_{2}\right)_{3}$-PDDA$\left(\mathrm{QD}_{\mathrm{CdTe}}\right)_{3}$-FTO, and $\left(\mathrm{TiO}_{2}\right)_{3}$-PDDA- $\left(\mathrm{QD}_{\mathrm{CdTe}}\right)_{4}$-FTO QDSSCs. Fig. 4 shows that the $\left(\mathrm{TiO}_{2}\right)_{3}$-PDDA- $\left(\mathrm{QD}_{\mathrm{CdTe}}\right)_{3}$-FTO QDSSC provided a clear shoulder at $550 \mathrm{~nm}$, with an IPCE of $26.0 \%$, while the $\left(\mathrm{TiO}_{2}\right)_{3}$-PDDA- $\left(\mathrm{QD}_{\mathrm{CdTe}}\right)_{4}$-FTO QDSSC provided a lower value of IPCE $(22.7 \%)$ at the same wavelength. Both the IPCE and absorption data indicate that the CdTe QDs in our QDSSCs harvested light at wavelengths ranging from 400 to $700 \mathrm{~nm}$.

\section{Conclusions}

We have demonstrated a new approach for the preparation of QDSSCs having high energy conversion efficiencies. To the best of our knowledge, this is the first example showing preparation of a wide size distribution of CdTe QDs on the electrode surface by conducting simple heating processes. Table 2 lists a comparison of our new developed solar cell with other $\mathrm{CdTe} / \mathrm{TiO}_{2}$ based solar cells. When compared to other techniques, our approach has the advantage of using environmentally friendly, room temperature ionic liquids solvent for the preparation of the electrolyte and CdTe prepared in aqueous solution. However, conducting several heating cycles is required; fabrication time is longer. Because variously sized CdTe QDs were adsorbed onto the $\left(\mathrm{TiO}_{2}\right)_{3}$-PDDA-FTO electrodes, the electrode absorbed light over a wider range in the UV-Vis region. As a result, the $\left(\mathrm{TiO}_{2}\right)_{3}$-PDDA-(QD $\left.\mathrm{CdTe}_{3}\right)_{3}$-FTO QDSSC provided a higher value of $\eta(2.02 \%)$ under illumination with $100 \%$ sunlight. Although we have used this approach to prepare QDSSCs featuring only CdTe QDs, we suspect that it could be applied further to the preparation of devices featuring other variously sized QDs, such as CdSe and ZnS, or mixtures of QDs, such as CdSe and CdTe QDs.

\section{Acknowledgements}

This study was supported by the National Science Council of Taiwan under contracts NSC 97-2627-M-002-010, and NSC 972627-M-002-011. We thank the Center for Information and Electronic Technologies at National Taiwan University for allowing us to conduct the SEM measurements. Z. Y. and Y.-W. L. thank National Taiwan University for PDF support (96R0044).

\section{References}

1 P. D. Thacker, Environ. Sci. Technol., 2005, 39, 436.

2 T. Warabisako, T. Uematsu, S. Muramatsu, K. Tsutsui, H. Ohtsuka, Y. Nagata and M. Sakamoto, Sol. Energy Mater. Sol. Cells, 1997, 48, 137.

3 B. O’Regan and M. Grätzel, Nature, 1991, 353, 737.

4 M. Grätzel, Nature, 2001, 414, 338.

5 M. K. Nazeeruddin, A. Key, I. Rodicio, R. Humphy-Baker, E. Müller, P. Liska, N. Vlachopoulos and M. Grätzel, J. Am. Chem. Soc., 1993, 115, 6382.

6 A. J. Nozik, Physica E, 2002, 14, 115.

7 R. T. Ross and A. J. Nozik, J. Appl. Phys., 1982, 53, 3813.

8 R. D. Schaller and V. I. Klimov, Phys. Rev. Lett., 2004, 92, 186601.

9 R. J. Ellingson, M. C. Beard, J. C. Johnson, P. Yu, O. I. Micic, A. J. Nozik, A. Shabaev and A. L. Efros, Nano Lett., 2005, 5, 865.

10 A. Zaban, O. I. Mićić, B. A. Gregg and A. J. Nozik, Langmuir, 1998, 14, 3153.

11 R. Plass, S. Pelet, J. Krueger and M. Grätzel, J. Phys. Chem. B, 2002, 106, 7578 .

12 I. Robel, V. Subramanian, M. Kuno and P. V. Kamat, J. Am. Chem. Soc., 2006, 128, 2385.

13 P. Yu, K. Zhu, A. G. Norman, S. Ferrere, A. J. Frank and A. J. Nozik, J. Phys. Chem. B, 2006, 110, 25451.

14 D. Kuang, C. Klein, S. Ito, J.-E. Moser, R. Humphry-Baker, N. Evan, F. Duriaux, C. Grätzel, S. M. Zakeeruddin and M. Grätzel, Adv. Mater., 2007, 19, 1133.

15 P. Wang, C. Klein, R. Humphry-Baker, S. M. Zakeeruddin and M. Grätzel, J. Am. Chem. Soc., 2005, 127, 808.

16 A. Kongkanand, K. Tvrdy, K. Takechi, M. Kuno and P. V. Kamat, J. Am. Chem. Soc., 2008, 130, 4007.

17 J. M. NedeljKović, O. I. Mićić, S. P. Ahrenkiel and A. Miedaner, J. Am. Chem. Soc., 2004, 126, 2632.

18 M. K. Nazeeruddin, P. Pechy, T. Renouard, S. M. Zakeeruddin, R. Humphry-Baker, P. Comte, P. Liska, L. Cevey, E. Costa, V. Shklover, L. Spiccia, G. B. Deacon, C. A. Bignozzi and M. Gratzel, J. Am. Chem. Soc., 2001, 123, 1613.

19 P. Wang, S. M. Zakeeruddin, P. Comte, I. Exnar and M. Gratzel, J. Am. Chem. Soc., 2003, 125, 1166.

20 P. Kawano and M. Watanabe, Chem. Commun., 2005, 2107.

21 N. Yamanaka, R. Kawano, W. Kubo, T. Kitamura, Y. Wada, M. Watanabe and S. Yanagida, Chem. Commun., 2005, 740.

22 P. Wang, S. M. Zakeeruddin, R. Humphry-Baker and M. Grätzel, Chem. Mater., 2004, 16, 2694. 
23 P. Wang, B. Wenger, R. Humphry-Baker, J.-E. Moser, J. Teuscher, W. Kantlehner, J. Mezger, E. V. Stoyanov, S. M. Zakeeruddin and M. Grätzel, J. Am. Chem. Soc., 2005, 127, 6850

24 P. K. Singh, K.-I. Kim, N.-G. Park and H.-W. R., Macromol. Symp., 2007, 249, 162

25 G. K. Zhang, X. M. Ding, F. S. He, X. Y. Yu, J. Zhou, Y. J. Hu and J. W. Xie, Langmuir, 2008, 24, 1026.

26 C.-Y. Chen, C.-T. Cheng, C.-W. Lai, Y.-H. Hu, P.-T. Chou, Y.-H. Chou and H.-T. Chiu, Small, 2005, 1, 1215.

27 Y.-W. Lin, W.-L. Tseng and H.-T. Chang, Adv. Mater., 2006, 18, 1381.

28 G.-H. Sun, K.-X. Li and C.-G. Sun, J. Power Sources, 2006, 162 1444.

29 M. Gao, A. L. Rogach, A. Kornowski, S. Kirstein, A. Eychmuller, H. Mohwald and H. Weller, J. Phys. Chem. B, 1998, 102, 8360.

30 N. Murase, P. Yang and C. L. Li, J. Phys. Chem. B, 2005, 109, 17855.

31 T. Herricks, J. Chen and Y. Xia, Nano Lett., 2004, 4, 2367.

32 S. Ito, T. Kitamura, Y. Wada and S. Yanagida, Sol. Energy Mater. Sol. Cells, 2003, 76, 3.
33 S. D. Burnside, V. Shklover, C. Barbé, P. Comte, F. Arendse, K. Brooks and M. Grätzel, Chem. Mater., 1998, 10, 2419.

34 J.-H. Yum, S. Nakade, D.-Y. Kim and S. Yanagida, J. Phys. Chem. B, 2006, 110, 3215.

35 K. Fredin, M. Gorlov, H. Pettersson, A. Hagfeldt, L. Kloo and G. Boschloo, J. Phys. Chem. C, 2007, 111, 13261.

36 Y.-M. Sung, K.-S. Park, Y.-J. Lee and T.-G. Kim, J. Phys. Chem. C, 2007, 111, 1239.

37 S.-C. Lin, Y.-L. Lee, C.-H. Chang, Y.-J. Shen and Y.-M. Yang, Appl. Phys. Lett., 2007, 90, 143517.

38 C.-H. Chang and Y.-L. Lee, Appl. Phys. Lett., 2007, 91, 053503.

39 M. Gratzel, Inorg. Chem., 2005, 44, 6841.

40 H.-J. Lee, D.-Y. Kim, J.-S. Yoo, J. Bang, S. Kim and S.-M. Park, Bull. Korean Chem. Soc, 2007, 28, 953.

41 J. A. Seabold, K. Shankar, R. H. T. Wilke, M. Paulose, O. K. Varghese, C. A. Grime and K.-S. Choi, Chem. Mater., 2008, 20, 5266 .

42 K. Ernst, R. Engelhardt, K. Ellmer, C. Kelch, H.-J. Muffler, M.-C. Lux-steiner and R. Könenkamp, Thin Solid Films, 2001, 387, 26. 